\title{
Application of Mentha suaveolens essential oil as an antimicrobial agent in fresh turkey sausages
}

\author{
Abdelaziz Ed-Dra ${ }^{1}$, Fouzia Rhazi Filai ${ }^{1 *}$, Mohamed Bou-Idra², Badr Zekkori², Aziz Bouymajane ${ }^{1}$, Najia Moukrad ${ }^{1}$, \\ Faouzia Benhallam ${ }^{1}$, Amar Bentayeb ${ }^{2}$ \\ ${ }^{1}$ Department of Biology, Team of Microbiology and Health, Laboratory of Chemistry-Biology Applied to the Environment, Moulay Ismail University, Faculty of \\ Sciences, BP. 11201 Zitoune Meknes, Morocco, ${ }^{2}$ Department of Chemistry, Team of Physical-Chemistry of Condensed Matter, Moulay Ismail University, Faculty \\ of Sciences, BP. 11201 Zitoune Meknes, Morocco
}

\begin{tabular}{l}
\hline ARTICLE INFO \\
\hline Article history: \\
Received on: June 20, 2017 \\
Accepted on: September 23, 2017 \\
Available online: January 17, 2018 \\
\hline Key words: \\
Mentha suaveolens, \\
Essential oil, \\
Antibacterial activity, \\
Food preservation, \\
Fresh sausage
\end{tabular}

\begin{abstract}
The aim of this study is to evaluate the antimicrobial effect of Mentha suaveolens essential oil against pathogenic bacteria in fresh turkey sausages. The essential oil was extracted by hydrodistillation. The antibacterial activity was carried out by agar diffusion and microplates methods against Escherichia coli, Salmonella, Staphylococcus aureus, Pseudomonas aeruginosa, Klebsiella pneumonia, and Streptococcus faecalis. The antioxidant activity was carried out by ferric reducing antioxidant power and free radical scavenging activities against 2,2-diphenyl-1-picrylhydrazyl. The antimicrobial effect on sausages was conducted by the enumeration of S. aureus and E. coli during the storage period of fresh sausages manufactured with different concentrations of essential oil. The results showed that the essential oil of $M$. suaveolens has an antibacterial effect against Gram-negative and Gram-positive bacteria in addition to its antioxidant activity $\left(\mathrm{EC}_{50}=3.95 \pm 0.03 \mathrm{mg} / \mathrm{mL}\right.$ and $\left.\mathrm{IC}_{50}=3.11 \pm 0.02 \mathrm{mg} / \mathrm{mL}\right)$. Moreover, the addition of essential oil to fresh sausages has a significant effect against the tested pathogenic bacteria. The present data clearly demonstrate that the essential oil of $M$. suaveolens has a remarkable antimicrobial and antioxidant activities and can be used as a food additive to extend the shelf life of food products.
\end{abstract}

\section{INTRODUCTION}

Sausage is a processed meat product, consists of chopped meat, water, binders, and seasonings, stuffed into natural or artificial casings. Its manufacture involves a number of handling steps, which increase the chances of its contamination by pathogenic bacteria (Escherichia coli O157:H7, Staphylococcus aureus, Salmonella...) through the contaminated raw meat, ingredients, processing equipment, and from postprocessing contamination [1]. These pathogens have also been detected in raw meat and have been shown to survive certain sausage manufacturing processes [2-4]; also, they are implicated in a large number of foodborne diseases outbreaks [5,6]. Moreover, the fresh sausage does not undergo heat treatment and has a high water activity giving it a short shelf life and subjecting it directly to the action of the microorganisms.

\footnotetext{
*Corresponding Author

Fouzia Rhazi Filai,

Team of Microbiology and Health,

Laboratory of Chemistry-Biology Applied to the Environment,

Moulay Ismail University, Faculty of Sciences,

BP. 11201 Zitoune Meknes, Morocco.

Tel: +212664488238 .

Email: Fouzia.filali@yahoo.fr
}

The manufacturers of sausages use the synthetic food conservatives to extend its shelf life, but these latter are limited in several countries because of their undesirable effects on health. For this reason, the use of natural additives is a primordial perspective to improve the bacteriological and organoleptic quality of food. Furthermore, the use of aromatic plants is a best choice with double effects; it contributes to the valorization of plant heritage of the regions threatened by poverty and provides the biological substances capable of replacing artificial ones. Some studies have shown that the treatment of sausages with essential oils makes it possible to inhibit the proliferation of pathogenic bacteria and to extend the shelf life of this product [7-9].

In Morocco, the Aromatic and Medicinal Plants sector records a sharp socioeconomic growth in recent years. It is one of the richest phytobiological fields in the world due to its diversity: 4200 species of plants including 800 endemics among them 382 species are known for their medicinal and/or aromatic use [10,11]. The genus Mentha is one of the important elements of Lamiaceae family; it is represented by 19 species and 13 natural hybrids [12]. Among its species include Mentha suaveolens which located in North Africa, Europe, America, and Japan [13]. This plant has a wide range of benefits: Analgesic, stomachic, choleretic, tonic, carminative action, antispasmodic, hypotensive, sedative, insecticide, anti-inflammatory, hepatoprotective, antimicrobials, acetylcholinesterase, and monoamine 
oxidase inhibitors, it is applied also in the treatment of digestion problems, influenza, respiratory diseases, rheumatisms, skin diseases, irritation, nausea, anorexia, and bronchitis [14-17].

Essential oils are complex natural mixtures of volatile secondary metabolites isolated from plants by hydrodistillation. Its chemical composition depends on the region and season and consists mainly of terpenoids including monoterpenes, sesquiterpenes, and their oxygen derivatives [13,17-19]. Formerly, essential oils of mint were used by the Egyptians, Romans, and Greeks populations as fragrances, food flavors, deodorizers, and pharmaceuticals products [20]. In recent years, some studies have indicated that the essential oils of $M$. suaveolens have an inhibitory effect on the proliferation of pathogenic bacteria [21]. Moreover, it has been reported that these essential oils possess also the antioxidant properties [22]. Thereby, in this study, we proceeded to (i) extract the essential oils of M. suaveolens harvested from Meknes Region in Morocco and (ii) evaluate its antibacterial and antioxidant activities, in addition to its effect in the survival of $E$. coli and $S$. aureus in fresh sausages. Moreover, it is important to note that the particularity of this work lies in the lack of preestablished research work on the effect of M. suaveolens essential oil on food conservation.

\section{MATERIALS AND METHODS}

\subsection{Plant Material and Essential Oil Extraction}

Samples were collected during March 2015. Extraction of essential oil was carried out by hydrodistillation for $3 \mathrm{~h}$ using a Clevenger-type apparatus. The plant material (about $100 \mathrm{~g}$ ) was placed in a flask (1 L) together with double distilled water $(500 \mathrm{~mL})$. The mixture was boiled for $3 \mathrm{~h}$ and the collected essential oils were dried over anhydrous sodium sulfate and stored in sealed glass vials at $4{ }^{\circ} \mathrm{C}$ in the dark until used.

\subsection{Antibacterial Activity}

The essential oils are insoluble in water and to allow its diffusion into the culture medium, it was solubilized in dimethyl sulfoxide (DMSO, Sigma-Aldrich). The antibacterial activity was performed on six strains belonging to Gram-negative and Gram-positive bacteria. Salmonella spp. and $S$. aureus were isolated from food in Laboratory of Microbiology and health at the Faculty of Sciences, Meknes. However, others pathogenic bacteria were collected from the Regional Hospital of Meknes (Mohammed V Hospital). Furthermore, E. coli (ATCC 25922) was used as a reference strain of this study. These strains are resistant to multiple antibiotics and their profile was determined according to the agar disk diffusion standard method [23] [Table 1].

\subsubsection{Disc diffusion assay}

In vitro antibacterial activity of $M$. suaveolens essential oil was evaluated against six bacterial strains by the disc diffusion method. A bacterial suspension equivalent to $0.5 \mathrm{McFarland}\left(10^{8} \mathrm{cfu} / \mathrm{mL}\right)$ was prepared and inoculated by swabbing on a Petri dish containing Mueller-Hinton agar (Biokar). On the surface of each Petri dish, $10 \mu \mathrm{L}$ of essential oil was dropped on $6 \mathrm{~mm}$ diameter filter paper discs (Whatman No. 4). A disc soaked in $10 \mu \mathrm{L}$ of DMSO was used as a negative control. Chloramphenicol $(30 \mu \mathrm{g})$ was used as a positive control for Streptococcus faecalis, imipenem $(10 \mu \mathrm{g})$ for Pseudomonas aeruginosa and gentamicin $(10 \mu \mathrm{g})$ to other strains. The used Petri dishes were incubated at $37^{\circ} \mathrm{C}$ for $18-24 \mathrm{~h}$. After incubation, the inhibition diameter was measured in millimeters (disk included). The strain will be nonsensitive if the diameter is less than $8 \mathrm{~mm}$, sensitive if the diameter varies between 9 and $14 \mathrm{~mm}$, very sensitive if the diameter varies between 15 and $19 \mathrm{~mm}$ and extremely sensitive if it's $>20 \mathrm{~mm}$ [24].

\subsubsection{Determination of minimum inhibitory concentration (MIC) and minimum bactericide concentration (MBC)}

MIC and MBC were performed according to the microplates method [25-27]. This method consists in inoculating a decreasing concentration of essential oil by a bacterial inoculum. After incubation, the range of bacterial growth indicates the MIC and MBC. The MIC is defined by the lowest concentration of essential oil capable of inhibiting the growth of $90 \%$ of the bacterial population. However, the $\mathrm{MBC}$ is the lowest concentration of essential oil capable of killing more than $99.9 \%$ of initial microbial inoculum.

\subsection{Antioxidant Activity}

\subsubsection{Evaluation of antioxidant activity by $\mathrm{Fe}$ (III) to $\mathrm{Fe}$ (II) reduction capacity}

The reduction of ferric to ferrous ion was used to determine the reductive capacity of essential oils [28]. Briefly, $1 \mathrm{~mL}$ of each concentration was mixed with $2.5 \mathrm{~mL}$ of potassium hexacyanoferrate $\mathrm{K}_{3} \mathrm{Fe}(\mathrm{CN})_{6}$ solution and $2.5 \mathrm{~mL}$ of phosphate buffer $(0.2 \mathrm{~mol} / \mathrm{L}, \mathrm{pH} 7.0)$ and incubated at $50^{\circ} \mathrm{C}$ for $30 \mathrm{~min}$. After, we added $2.5 \mathrm{~mL}$ of trichloroacetic acid $(10 \%)$ to the mixture. Then, $2.5 \mathrm{~mL}$ of this solution was homogenized with distilled water $(2.5 \mathrm{~mL})$ and $\mathrm{FeCl}_{3}(0.5 \mathrm{~mL}, 0.1 \%)$. The absorbance was measured at $700 \mathrm{~nm}$ and the concentration of the samples at which the absorbance of $0.5\left(\mathrm{EC}_{50}\right)$ was determined. Ascorbic acid was used as positive control for comparison.

\subsubsection{Evaluation of antioxidant activity by 2,2-diphenyl-1- picrylhydrazyl (DPPH) radical scavenging method}

The purple-colored methanol solution of DPPH was used to measure the electron donation ability of the plant essential oils and some pure compounds [29]. In this study, $2 \mathrm{~mL}$ of different essential oils concentrations were homogenized with $1 \mathrm{~mL}$ of $0.2 \mathrm{mM}$ solution of DPPH and incubated in the dark for $30 \mathrm{~min}$. After, the absorbance (A) of the resulting solution was measured at $517 \mathrm{~nm}$ [30]. The inhibition percentage was calculated as follows:

$\%$ Inhibition $=\frac{(\text { A blank }- \text { A sample })}{\text { A blank }} \times 100$

The concentration providing $50 \%$ inhibition $\left(\mathrm{IC}_{50}\right)$ was calculated from the graph and ascorbic acid was used as positive control.

\subsection{Antimicrobial Activity in a Food System}

To evaluate the antimicrobial activity of $M$. suaveolens essential oil in a food system, a sufficient amount of fresh sausage was prepared according to the method described previously [31] and mixed with three distinct oil concentrations $(2 \mathrm{mg} / \mathrm{g}, 5 \mathrm{mg} / \mathrm{g}$, and $10 \mathrm{mg} / \mathrm{g})$. In addition to these tests, a negative control containing no oil was also used. Three batches were prepared for each concentration. Then, they were inoculated with $S$. aureus and E. coli at a concentration of $10^{6} \mathrm{cfu} / \mathrm{g}$ and stored at $4^{\circ} \mathrm{C}$ for $48 \mathrm{~h}$. The microbiological analysis was carried out during $0,6,24$, and $48 \mathrm{~h}$. Briefly, a sausage samples (10 g) of each batch were mixed with $90 \mathrm{~mL}$ of sterile peptone water (Biokar), the decimal dilutions were prepared. S. aureus was enumerated on BairdParker agar (Biokar) with egg yolk tellurite emulsion and incubated at $37^{\circ} \mathrm{C}$ for 48 h. E. coli was enumerated on Rapid E. coli 2 Agar (Bio$\mathrm{Rad})$ after $24 \mathrm{~h}$ of incubation at $44^{\circ} \mathrm{C}$. 


\subsection{Statistical Analyses}

Measurements were carried out in triplicate. The data obtained were presented as means \pm standard error and the significance of difference between test and control groups was statistically analyzed using Fisher least significant difference test. A probability level of $P<0.05$ was used in testing the statistical significance of all experimental data. All the statistical analyses were achieved using the Microsoft Excel and XLSTAT.

\section{RESULTS}

\subsection{Antibacterial Activity}

The results show an inhibition of bacterial growth proportional to the diameter zone [Figure 1]. Furthermore, the inhibition diameters produced by essential oil vary according to the bacterial strain. The highest inhibition zone is observed in $S$. aureus $(21 \pm 1 \mathrm{~mm})$, followed by E. coli $(17 \pm 0.5 \mathrm{~mm})$, Klebsiella pneumonia $(16 \pm 0.5 \mathrm{~mm})$, Streptococcus faecalis $(14 \pm 0.5 \mathrm{~mm})$, Salmonella spp. (14 $\pm 0.4 \mathrm{~mm})$, and $P$. aeruginosa $(13 \mathrm{~mm} \pm 0.3)$. The MIC varies between a minimum of $0.48 \mathrm{mg} / \mathrm{mL}$ detected in $S$. aureus and a maximum of $7.81 \mathrm{mg} / \mathrm{mL}$ detected in Salmonella spp. and $P$. aeruginosa. Furthermore, the MBC varies between a minimum of $0.48 \mathrm{mg} / \mathrm{mL}$ detected in $S$. aureus and $15.62 \mathrm{mg} / \mathrm{mL}$ detected in $P$. aeruginosa. The ratio of MBC/MIC fluctuates between 1 and 2 [Table 2].

\subsection{Antioxidant Activity}

The reducing ability of a compound can serve as a significant indicator of its potential antioxidant. In the present study, the ferric reducing antioxidant power (FRAP) method was used to test the antioxidant capacity of $M$. suaveolens essential oil by reducing the ferric ion $\mathrm{Fe}^{3+}$ to the ferrous ion $\mathrm{Fe}^{2+}$. The results obtained show that the iron reduction capacity was proportional to the concentration of essential oil. Furthermore, these results show that the ability of this essential oil to reduce the iron was less than that of ascorbic acid and reached the maximum at a concentration of $12.5 \mathrm{mg} / \mathrm{mL}$. However, the ascorbic acid was reached a total reduction at a concentration of $0.75 \mathrm{mg} / \mathrm{mL}$ [Figure 2]. The $\mathrm{EC}_{50}$ of essential oil and ascorbic acid was $3.95 \pm$ $0.03 \mathrm{mg} / \mathrm{mL}$ and $0.11 \pm 0.02 \mathrm{mg} / \mathrm{mL}$, respectively, [Table 3]. In the other hand, the reduction of DPPH is accompanied by its passage from the violet color characteristic of DPPH solution to the yellow color measurable at 514-518 nm. In this study, the absorbance (OD) was measured by spectrophotometry at $517 \mathrm{~nm}$, and the percentage of inhibition was calculated using the formula given above. The concentration necessary to reduce $50 \%$ of the DPPH radical $\left(\mathrm{IC}_{50}\right)$ was $3.11 \pm 0.02 \mathrm{mg} / \mathrm{mL}$ and $0.25 \pm 0.01 \mathrm{mg} / \mathrm{mL}$ for essential oil and ascorbic acid, respectively [Table 3].

\subsection{Antimicrobial Activity in a Food System}

The effect of $M$. suaveolens essential oil was evaluated by the enumeration of E. coli and $S$. aureus during the storage period of fresh sausages manufactured by different concentrations of this essential oil. The results show that the survival of $E$. coli and $S$. aureus in fresh turkey sausages depends significantly on the essential oil concentration and storage duration [Table 4].

\section{DISCUSSION}

The antibacterial activity of $M$. suaveolens essential oil shows that $S$. aureus is extremely sensitive with an inhibition zone of $21 \pm 1 \mathrm{~mm}$ and a MIC of $0.48 \mathrm{mg} / \mathrm{mL}$. However, the others bacteria tested have an inhibition zone between $13 \pm 0.3$ and $17 \pm 0.5 \mathrm{~mm}$ and a MIC between



Figure 1: Zones of growth inhibition ( $\mathrm{mm}$ ) for Mentha suaveolens essential oil against pathogenic bacteria. Disc diameter $6.0 \mathrm{~mm} ;$ E. coli*: Escherichia coli ATCC 25922; E. coli: Escherichia coli; Sal: Salmonella spp.; P.a Pseudomonas aeruginosa; K.p: Klebsiella pneumonia; S.f: Streptococcus faecalis; S.a: Staphylococcus aureus

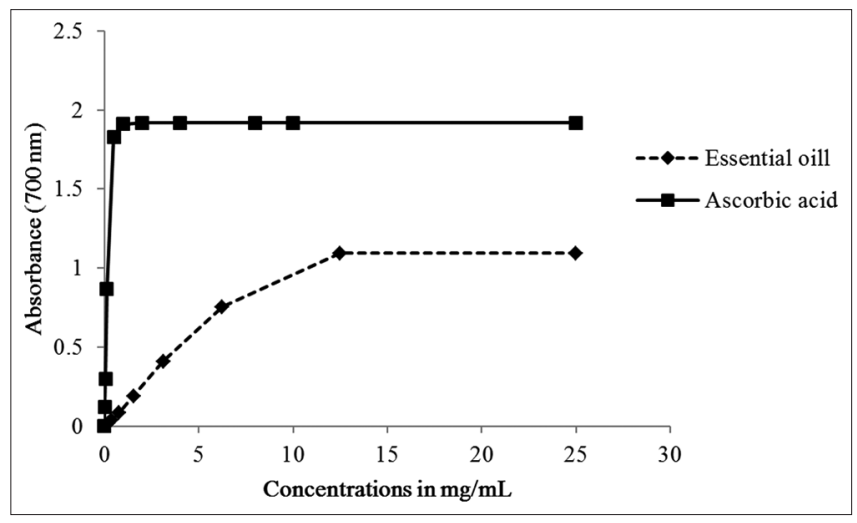

Figure 2: The reducing power of ascorbic acid and Mentha suaveolens essential oil

1.95 and $7.81 \mathrm{mg} / \mathrm{mL}$. The ratio of $\mathrm{CMB} / \mathrm{CMI}$ is $<4$ for all the bacteria tested which shows that this essential oil has a bactericidal effect [32].

The antimicrobial activity of essential oils depends on their hydrophilic or lipophilic characteristics. However, the mechanism of essential oils action on microorganisms is complex and related with the ability to cause injury to the phospholipids present in cell membranes, resulting in higher permeability and leakage of the cytoplasm, or by its interaction with other enzymes present in the cell wall [33]. The high susceptibility of Gram-positive bacteria to essentials oils in comparing with Gramnegative bacteria might be explained by the higher susceptibility of its cell wall to the lipophilic components of essential oils. Moreover, the lower sensibility of Gram-negative bacteria can be explained by the difficulty of essential oils to diffuse through the hydrophilic barrier of the cell wall [34]. Other studies carried out previously showed that the essential oil of $M$. suaveolens had a significant effect on the eradication of Gram-positive bacteria [35,36].

The antioxidant activity of a compound corresponds to its capacity to resist oxidation. Many methods are currently used to evaluate this activity. In this study, the reducing capacity of iron (FRAP) and the DPPH radical scavenging activity methods are used. The results 
Table 1: Bacteria tested with their antibiotic resistance profile.

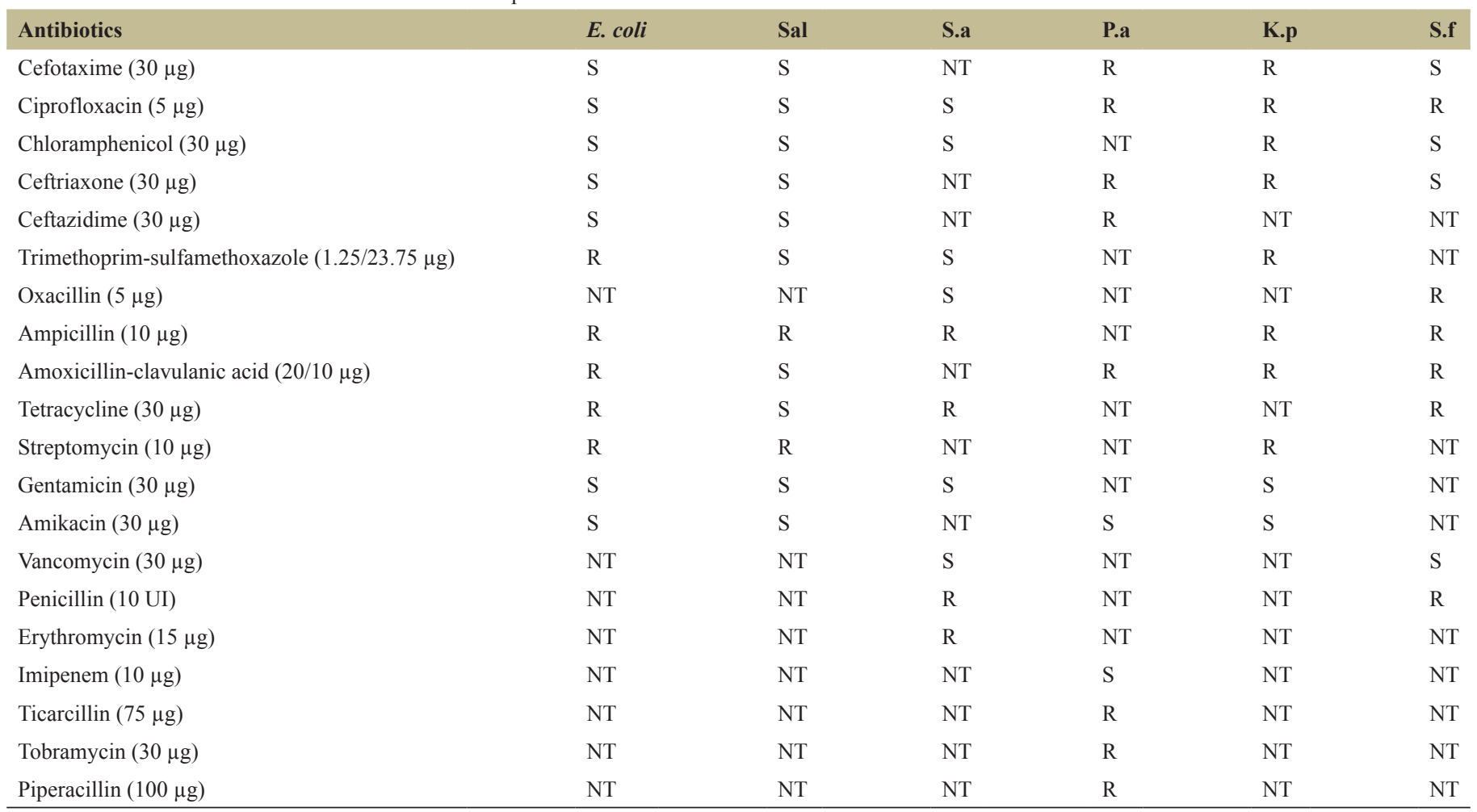

R: Resistant, S: Sensitive, NT: The antibiotic is not tested, E. coli: Escherichia coli, Sal: Salmonella spp., P.a: Pseudomonas aeruginosa, K.p: Klebsiella pneumonia, S.f: Streptococcus faecalis, S.a: Staphylococcus aureus

Table 2: Results for MIC and MBC for Mentha suaveolens essential oil.

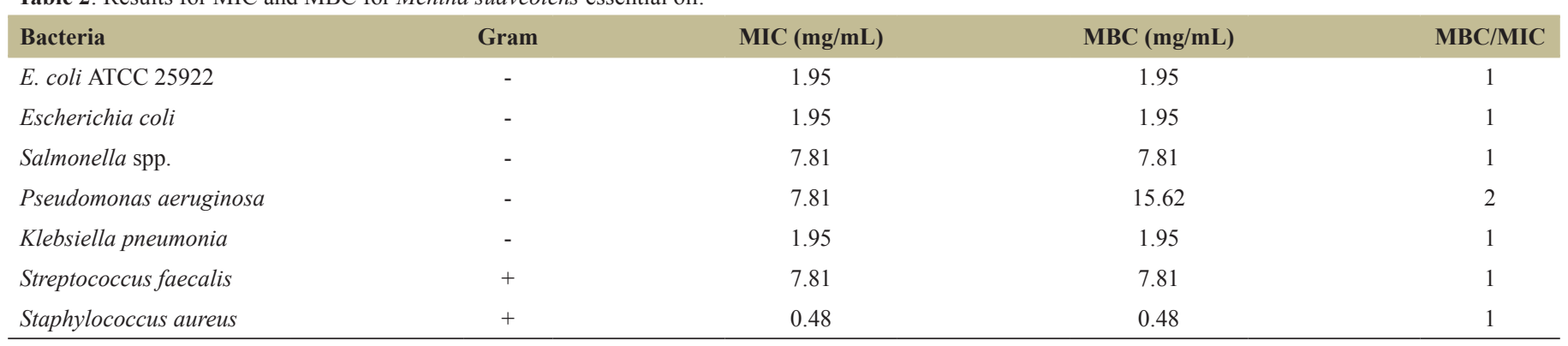

MBC: Minimum bactericide concentration, MIC: Minimum inhibitory concentration

Table 3: The $\mathrm{IC}_{50}$ values $(\mathrm{mg} / \mathrm{ml})$ of Mentha suaveolens essential oil and ascorbic acid.

\begin{tabular}{lcc} 
Antioxidant Activity & Mentha suaveolens essential oil & Ascorbic acid \\
$\mathrm{IC}_{50}(\mathrm{mg} / \mathrm{mL})$ & $3.11 \pm 0.02$ & $0.25 \pm 0.01$ \\
$\mathrm{EC}_{50}(\mathrm{mg} / \mathrm{mL})$ & $3.95 \pm 0.03$ & $0.11 \pm 0.02$ \\
\hline
\end{tabular}

show that the essential oils of $M$. suaveolens have a remarkable antioxidant activity but lower than that of ascorbic acid. This may be due to the limitation of these essential oils in substances that have powerful antioxidant capabilities such as flavonoids [37,38]. However, it exhibits this activity at concentrations compatible with their bactericidal effect. On the other hand, it has been reported in the literature that $M$. suaveolens is a plant rich in essential oil and endowed with a potent antibacterial and antioxidant activity $[21,22]$.

The plant essential oils have attracted interest as potential preservatives because they are generally recognized as safe and have a wide acceptance from consumers. Indeed, the antimicrobial activity of various plant species has been known for a long time and used to extend the shelf life of food products [39]. Moreover, the species those belonging to Lamiaceae family have been used for a long time for improving the taste and organoleptic properties of different foods [40]. This effect is due to the essential oil fraction contained in the plant's species which inhibits the growth of pathogenic bacteria, fungi, and yeasts $[26,41,42]$. Furthermore, several studies have demonstrated the activity of essential oils against pathogens in food systems [7-9]. In the same way, the present study shows that under the effect of $M$. suaveolens essential oil; there is an important abatement of $S$. aureus and $E$. coli during the storage period, these pathogens have been cited among the most incriminated in food poisoning [43-46]. In addition, the use of essential oils in food preservation makes it possible to improve the taste quality and to give a taste appreciated for the consumer [7].

\section{CONCLUSION}

The essential oil of $M$. suaveolens has an important antibacterial activity against several multiresistant pathogenic bacteria, in addition 
Ed-Dra, et al.: Antibacterial effect of M. suaveolens in sausages. 2018;6(1):7-12

Table 4: Level variations of Escherichia coli and Staphylococcus aureus during the storage of sausages supplemented with Mentha suaveolens essential oil

\begin{tabular}{|c|c|c|c|c|c|}
\hline \multirow[t]{2}{*}{ Bacteria } & \multirow[t]{2}{*}{ Time } & \multicolumn{4}{|c|}{ Concentrations of essential oil } \\
\hline & & Blank & $2 \mathrm{mg} / \mathrm{g}$ & $5 \mathrm{mg} / \mathrm{g}$ & $10 \mathrm{mg} / \mathrm{g}$ \\
\hline \multirow[t]{3}{*}{ Escherichia coli (Log cfu/g) } & $0 \mathrm{~h}$ & $6.3 \pm 0.2^{\mathrm{B}}$ & $6.3 \pm 0.2^{\mathrm{B}}$ & $6.3 \pm 0.2^{\mathrm{B}}$ & $6.3 \pm 0.2^{\mathrm{B}}$ \\
\hline & $24 \mathrm{~h}$ & $6.67 \pm 0.1^{\mathrm{A}}$ & $6.03 \pm 0.1^{\mathrm{C}}$ & $5.69 \pm 0.2^{\mathrm{E}}$ & $5.37 \pm 0.2^{\mathrm{F}}$ \\
\hline & $48 \mathrm{~h}$ & $6.84 \pm 0.1^{\mathrm{A}}$ & $5.77 \pm 0.1^{\mathrm{DE}}$ & $5.14 \pm 0.1^{\mathrm{G}}$ & $4.63 \pm 0.3^{\mathrm{H}}$ \\
\hline \multirow[t]{3}{*}{ Staphylococcus aureus (Log cfu/g) } & $0 \mathrm{~h}$ & $6.3 \pm 0.3^{\mathrm{BC}}$ & $6.3 \pm 0.3^{\mathrm{BC}}$ & $6.3 \pm 0.3^{\mathrm{BC}}$ & $6.3 \pm 0.3^{\mathrm{BC}}$ \\
\hline & $24 \mathrm{~h}$ & $6.59 \pm 0.1^{\mathrm{AB}}$ & $5.86 \pm 0.1^{\mathrm{DE}}$ & $4.97 \pm 0.15^{\mathrm{F}}$ & $4.44 \pm 0.1^{\mathrm{G}}$ \\
\hline & $48 \mathrm{~h}$ & $6.8 \pm 0.2^{\mathrm{A}}$ & $5.51 \pm 0.2^{\mathrm{E}}$ & $4.34 \pm 0.1^{\mathrm{G}}$ & $3.63 \pm 0.2^{\mathrm{H}}$ \\
\hline
\end{tabular}

Data are averages ( \pm standard errors). Different letters stand for statistically significant differences at $P<0.05$ (Fisher's LSD). LSD: Least significant difference

to its antioxidant activity. Furthermore, the results of this study showed that this essential oil can be used as a natural food additive for the conservation and improvement of the hygienic quality of food products.

\section{REFERENCES}

1. Ed-dra A, Rhazi Filali F, El-Allaoui A, Aboulkacem A. Factors influencing the bacteriological quality of sausages sold in Meknes city, Morocco. Int Food Res J 2017;24:933-8.

2. Hwang CA, Porto-Fett AC, Juneja VK, Ingham SC, Ingham BH, Luchansky JB. Modeling the survival of Escherichia coli O157:H7, Listeria monocytogenes, and Salmonella typhimurium during fermentation, drying, and storage of soudjouk-style fermented sausage. Int J Food Microbiol 2009;129:244-52.

3. Campbell JA, Dickson JS, Cordray JC, Olson DG, Mendonca AF, Prusa KJ. Survival of methicillin-resistant Staphylococcus aureus during thermal processing of frankfurters, summer sausage, and ham. Foodborne Pathog Dis 2014;11:50-4.

4. Ed-Dra A, Filali FR, Karraouan B, El Allaoui A, Aboulkacem A, Bouchrif B. Prevalence, molecular and antimicrobial resistance of Salmonella isolated from sausages in Meknes, Morocco. Microb Pathog 2017;105:340-5.

5. Argudín MÁ, Mendoza MC, Rodicio MR. Food poisoning and Staphylococcus aureus enterotoxins. Toxins (Basel)2010;2:1751-73.

6. Gould LH, Mody RK, Ong KL, Clogher P, Cronquist AB, Garman KN, et al. Increased recognition of non-O157 shiga toxinproducing Escherichia coli infections in the United States during 2000-2010: Epidemiologic features and comparison with E. coli O157 infections. Foodborne Pathog Dis 2013;10:453-60.

7. Busatta C, Vidal RS, Popiolski AS, Mossi AJ, Dariva C, Rodrigues $\mathrm{MR}$, et al. Application of Origanum majorana L. essential oil as an antimicrobial agent in sausage. Food Microbiol 2008;25:207-11.

8. Tajkarimi MM, Ibrahim SA, Cliver DO. Antimicrobial herb and spice compounds in food. Food Control 2010;21:1199-218.

9. Barbosa LN, Probst IS, Murbach Teles Andrade BF, Bérgamo Alves FC, Albano M, Mores Rall VL, et al. Essential oils from herbs against foodborne pathogens in chicken sausage. J Oleo Sci 2015;64:117-24.

10. Hmammouchi M. Les Plantes Médicinales et Aromatiques Marocaines. Utilisations, Biologie, Ecologie, Chimie, Pharmacologie, Toxicologie et Lexiques. Rabat: Fédala Press; 1999. p. 1-177.

11. Jamila F, Mostafa E. Ethnobotanical survey of medicinal plants used by people in Oriental Morocco to manage various ailments. J Ethnopharmacol 2014;154:76-87.

12. El-Kashoury ES, El-Askary HI, Kandil ZA, Taher EE, Salem MA. Molluscicidal and mosquitocidal activities of the essential Oil of
Mentha suaveolens Ehrh. Cultivated in Egypt. J Essent Oil Bearing Plants 2015;18:436-43.

13. Sutour S, Bradesi P, Casanova J, Tomi F. Composition and chemical variability of Mentha suaveolens ssp. Suaveolens and M. suaveolens ssp. Insularis from Corsica. Chem Biodivers 2010;7:1002-8.

14. Bellakhdar J. Medicinal plants in North Africa and basic care. Hand book of Modern Herbal Medicine. Casablanca: Le Fennec Press; 1996. p. 1-98.

15. Moreno L, Bello R, Primo-Yúfera E, Esplugues J. Pharmacological properties of the methanol extract from Mentha suaveolens Ehrh. Phytother Res 2002;16 Suppl 1:S10-3.

16. Karousou R, Balta M, Hanlidou E, Kokkini S. "Mints", smells and traditional uses in Thessaloniki (Greece) and other Mediterranean countries. J Ethnopharmacol 2007;109:248-57.

17. Božović M, Pirolli A, Ragno R. Mentha suaveolens Ehrh. (Lamiaceae) essential oil and its main constituent piperitenone oxide: Biological activities and chemistry. Molecules 2015;20:8605-33.

18. Brada M, Bezzina M, Marlier M, Carlier A, Lognay G. Variability of the chemical composition of Mentha rotundifolia from Northern Algeria. Biotechnol Agron Soc Environ 2007;11:3-7.

19. Abbaszadeh B, Valadabadi SA, Farahani HA, Darvishi HH. Studying of essential oil variations in leaves of Mentha species. Afr J Plant Sci 2009;3:217-21.

20. Kumar P, Mishra S, Malik A, Satya S. Insecticidal properties of Mentha species: A review. Ind Crops Prod 2011;34:802-17.

21. Oumzil H, Ghoulami S, Rhajaoui M, Ilidrissi A, Fkih-Tetouani S, Faid M, et al. Antibacterial and antifungal activity of essential oils of Mentha suaveolens. Phytother Res 2002;16:727-31.

22. El-Kashoury el-SA, El-Askary HI, Kandil ZA, Salem MA, Sleem AA. Chemical composition and biological activities of the essential oil of Mentha suaveolens Ehrh. Z Naturforsch C 2012;67:571-9.

23. Clinical and Laboratory Standards Institute. Performance Standards for Antimicrobial Susceptibility Testing; 24 $4^{\text {th }}$ Informational Supplement. CLSI Document M100-S24. Wayne, PA: Clinical and Laboratory Standards Institute; 2014. p. 50-108.

24. Ponce AG, Fritz R, Valle CD, Roura SI. Antimicrobial activity of essential oils on the native micro flora of organic Swiss chard. LWT Food Sci Technol 2003;36:679-84.

25. Eloff JN. A sensitive and quick micro plate method to determine the minimal inhibitory concentration of plant extracts for bacteria. Planta Med 1998;64:711-3.

26. Chebaibi A, Marouf Z, Rhazi-Filali F, Fahim M, Ed-Dra A. Evaluation of antimicrobial activity of essential oils from seven Moroccan medicinal plants. Phytothérapie 2016;14:355-62.

27. Jahanpanahi M, Sani AM. Antimicrobial effect of nanofluid including zinc oxide $(\mathrm{ZnO})$ nanoparticles and Mentha pulegium essential oil. J Appl Biol Biotechnol 2016;4:85-9.

28. Dorman HJ, Peltoketo A, Hiltunen R, Tikkanen MJ. Characterisation 
of the antioxidant properties of de-odourised aqueous extracts from selected Lamiaceae herbs. Food Chem 2003;83:255-62.

29. Kubola J, Siriamornpun S. Phenolic contents and antioxidant activities of bitter gourd (Momordica charantia L.) leaf, stem and fruit fraction extracts in vitro. Food Chem 2008;110:881-90.

30. Abdallah EM, Elsharkawy EM, Ed-dra A. Biological activities of methanolic leaf extract of Ziziphus mauritiana. Biosci Biotechnol Res Commun 2016;9:605-14.

31. Benkerroum N, Daoudi A, Kamal M. Behaviour of Listeria monocytogenes in raw sausages (merguez) in presence of a bacteriocin-producing lactococcal strain as a protective culture. Meat Sci 2003;63:479-84.

32. Levison ME. Pharmacodynamics of antimicrobial drugs. Infect Dis Clin North Am 2004;18:451-65.

33. Kalemba D, Kunicka A. Antibacterial and antifungal properties of essential oils. Curr Med Chem 2003;10:813-29.

34. Walker JF, Santos PD, Schmidt CA, Bittencourt TC, Guimarães AG. Antimicrobial activity of marjoram (Origanum majorana) essential oil against the multidrug-resistant Salmonella enterica serovar schwarzengrund inoculated in vegetables from organic farming. J Food Saf 2016;36:489-96.

35. Cimanga K, Kambu K, Tona L, Apers S, De Bruyne T, Hermans N, et al. Correlation between chemical composition and antibacterial activity of essential oils of some aromatic medicinal plants growing in the democratic republic of congo. J Ethnopharmacol 2002;79:213-20.

36. Burt S. Essential oils: Their antibacterial properties and potential applications in foods - a review. Int J Food Microbiol 2004;94:223-53.

37. Couic-Marinier F, Lobstein A. Chemical composition of essential oils. Actualités Pharm 2013;52:22-5.

38. Wybranowski T, Ziomkowska B, Kruszewski S. Antioxidant properties of flavonoids and honeys studied by optical spectroscopy methods. Med Biol Sci 2014;27:53-8.

39. Hulin V, Mathot AG, Mafart P, Dufosse L. Antimicrobial properties of essential oils and flavour compounds. Sci Aliment 1998;18:563-82.
40. Bozin B, Mimica-Dukic N, Simin N, Anackov G. Characterization of the volatile composition of essential oils of some Lamiaceae spices and the antimicrobial and antioxidant activities of the entire oils. J Agric Food Chem 2006;54:1822-8.

41. Hammer KA, Carson CF, Riley TV. Antimicrobial activity of essential oils and other plant extracts. J Appl Microbiol 1999;86:985-90.

42. Bouchra C, Achouri M, Idrissi Hassani LM, Hmamouchi M. Chemical composition and antifungal activity of essential oils of seven Moroccan Labiatae against Botrytis cinerea pers: Fr. J Ethnopharmacol 2003;89:165-9.

43. Bandyopadhyay S, Lodh C, Rahaman H, Bhattacharya D, Bera AK, Ahmed FA, et al. Characterization of shiga toxin producing (STEC) and enteropathogenic Escherichia coli (EPEC) in raw yak (Poephagus grunniens) milk and milk products. Res Vet Sci 2012;93:604-10.

44. Al-Zogibi OG, Mohamed MI, Hessain AM, El-Jakee JK, Kabli SA. Molecular and serotyping characterization of shiga toxogenic Escherichia coli associated with food collected from Saudi Arabia. Saudi J Biol Sci 2015;22:438-42.

45. Kadariya J, Smith TC, Thapaliya D. Staphylococcus aureus and staphylococcal food-borne disease: An ongoing challenge in public health. Biomed Res Int 2014;2014:827965.

46. Abdalrahman LS, Stanley A, Wells H, Fakhr MK. Isolation, virulence, and antimicrobial resistance of methicillin-resistant Staphylococcus aureus (MRSA) and methicillin sensitive Staphylococcus aureus (MSSA) strains from Oklahoma retail poultry meats. Int J Environ Res Public Health 2015;12:6148-61.

\section{How to cite this article:}

Ed-dra A, Rhazi Filai F, Bou-Idra M, Zekkori B, Bouymajane A,

Moukrad A, Bentayed A. Application of Mentha suaveolens essential oil as an antimicrobial agent in fresh turkey sausages. J App Biol Biotech.

2018;6(1):7-12. DOI: 10.7324/JABB.2018.60102 